v. 14, n. 1

Vitória-ES, Jan-Feb. 2017

p. 21-41 ISSN 1808-2386

DOI:http://dx.doi.org/10.15728/bbr.2017.14.1.2

\title{
Corporate Social-Environmental Responsibility as an Attraction and Retention Factor for Young Professionals
}

\author{
Marcos Cohen ${ }^{\dagger}$ \\ Pontifícia Universidade Católica do Rio de Janeiro \\ Flávia de Souza Costa Neves Cavazotte ${ }^{\Omega}$ \\ Pontifícia Universidade Católica do Rio de Janeiro \\ Taissa Mattos da Costa ${ }^{\sharp}$ \\ Pontificia Universidade Católica do Rio de Janeiro \\ Karina Cordeiro Silva Ferreira* \\ Pontifícia Universidade Católica do Rio de Janeiro
}

\begin{abstract}
This research investigates if company social-environmental responsibility (SER) is an attraction and retention factor for young professionals in two studies. The first study, an experiment, investigates whether such practices influence the attraction exerted by the company as a prospect employer among undergraduate students, considering different wage and professional development conditions. The second study, a survey, investigates the impact of company SER on voluntary turnover among trainees, controlling for individual differences and satisfaction with income, growth and interests. The results suggest that SER is an important element in the attractiveness exercised by companies as they recruit young professionals, and in the retention of trainees, since it is statistically associated with the likelihood of them leaving their companies after disputed selection processes and expensive training programs.
\end{abstract}

Keywords: Social-environmental responsibility; Attraction; Recruitment; Retention.

\footnotetext{
*Author for correspondence:

${ }^{\dagger}$. Doutor em Administração de Empresas (PUC-Rio) Institution: PUC-Rio Rua Marquês de São Vicente, $n^{\circ} 225$ Gávea, Rio de Janeiro - RJ

Brazil - Zip Code 22451-900

E-mail: mcohen@iag.puc-rio.br
}

$\Omega$. Ph.D. Business Administration Institution: PUC-Rio

Rua Marquês de São Vicente, $n^{\circ} 225$

Gávea, Rio de Janeiro - RJ

Brazil - Zip Code 22451-900

E-mail: flavia.cavazotte@iag.puc-rio.br
¥. Bacharel em Administração Institution: PUC-Rio

Rua Marquês de São Vicente, no 225

Gávea, Rio de Janeiro - RJ

Brazil - Zip Code 22451-900

E-mail: taissa@claveconsultoria.com.br
*. Bacharel em Administração Institution: PUC-Rio

Rua Marquês de São Vicente, n ${ }^{0} 225$

Gávea, Rio de Janeiro - RJ

Brazil - Zip Code 22451-900

E-mail: karinac.f@hotmail.com

Note from the Editor: The article was accepted by Bruno Felix.

(c) ) BY

This article has a Creative Commons License - Attribution 3.0 Not Adapted. 


\section{INTRODUCTION}

$\mathrm{W}$

ith the increasing competition between companies both locally and globally, human capital recruitment and retention has become critical to businesses. Meanwhile, institutional and market pressures for greater company commitment with social and environmental issues have also expanded, calling attention to the way companies respond to these issues, which impacts their image and reputation before various stakeholders, including current and future employees.

The academic literature on sustainability, environmental management and corporate social responsibility (CSR) has proposed and investigated several benefits of company initiatives in these areas, analyzing the effects of such practices on the attraction of new customers (ARORA; HENDERSON, 2007), the ability to generate value for shareholders (SEN; BHATTACHARYA; KORSCHUN, 2006) and the improvement of financial and operational performance through competitive advantage (HAMMES et al., 2012). The richness of this research field reveals a growing concern on the part of various stakeholders with the impact of company's operations on society and the environment. The degree of responsibility assumed by a company regarding those issues seems to have become an important element that can affect their image and identity, influencing public judgment and the attitudes of several stakeholders, whether they are investors, consumers or employees (e.g.: BRAMMER; PAVELIN, 2006).

The goal of this study is to analyze the relationship between Social-Environmental Responsibility (SER) and people management in organizations. Some authors have discussed the influence of social and environmental practices on the capacity of companies to attract and retain new talent, based on the understanding that human capital is a major source of competitive advantage and organizational growth (e.g.: BARNEY, 1991; PLOYHART; MOLITERNO, 2011). According to contemporary thinking on companies attractiveness and employment choice, individuals do not decide to enter into a particular organization merely by financial rewards (BOHLANDER; SNELL; SHERMAN, 2005). There are several subjective factors associated with the image and reputation of companies that make them more or less attractive (BERTHON, 2005). When these elements associated with the identity of the organization, i.e., principles and distinctive values assigned to the enterprise, are congruent with the individual and their reference groups, the company's ability to attract and retain employees would be potentialized (LIEVENS; HIGHHOUSE, 2003; RABELO; SILVA, 2011).

Since thenew generations have had more and earlier exposure to the debate on the environmental crisis and sustainability (SORRENTINO; TRAJBER; MENDONÇA,2005), exhibit knowledge and show awareness to environmental issues (BORGES; DUBEUX; PEREIRA, 2012) and expect from companies responsible actions regarding environmental issues (CAVAZOTTE; LEMOS; 
VIANA, 2012), it is believed that the company's conduct in this sphere can be an attractive factor for this group (FARIA; FERREIRA; CARVALHO, 2012), and that companies' practices aligned to these values can be a relevant factor in the retention and longevity of the bonds of this group with organizations.

Although social responsibility and environmental responsibility are dimensions of corporate sustainability, companies have generally applied them in a disintegrated way, within different functional areas. Recently, we note companies efforts to integrate these actions within the Sustainability functional area. The very concept of CSR has evolved to encompass environmental issues, as noted in the ISO 26000 standards. Thus, it is now usual to find companies and researchers using the term "Social-Environmental Responsibility" - SER (AMARAL; MARSON, 2013; NASCIMENTO; LEMOS; MELLO, 2008). In this article, we consider that the CSR term also includes the concern for environmental issues, thus justifying the option for using the term SER (Social-Environmental Responsibility) throughout the text. A single exception occurred in study 2, when we used the term CSR to maintain consistency with the methodology proposed by Heger (2007). Still, one must understand that this term embeds both social as environmental and ethical concerns.

\section{THEORETICAL FRAMEWORK}

\subsection{Social and environmental practices in the context of Corporate Sustainability}

Since the formulation of the corporate sustainability concept through the Triple Bottom Line approach (ELKINGTON, 1994), the adoption of sustainable practices is growing among small and large corporations (WAJNBERG;LEMME, 2009). A sustainable company is one that considers in its actions the economic, social and environmental dimensions, i.e., it seeks profit, but reduces the negative impact of its activities on the environment efficiently, through environmental management, and performs social actions for the community, through social responsibility (AZEVEDO, 2011).

Corporate Social Responsibility (CSR) is related to a company concern to fulfill its responsibilities to multiple stakeholders which exist in the economic, legal, ethical and philanthropic levels (CARROLL, 1991). Nascimento, Lemos and Mello (2008) define it as the company's initiatives that benefit society and corporations, by considering factors such as economy, education, environment, health, transportation, housing, local activity and government. Thus, for some authors, CSR is considered the way companies get legitimation and society support to their goals and activities (AMARAL; MARSON,2013; SANTOS, 2013).

Although social responsibility and environmental responsibility are dimensions of corporate sustainability, companies have generally applied them in a disintegrated way, within different functional areas. Recently, we note companies efforts to integrate these actions within the 
Sustainability functional area. The very concept of CSR has evolved to encompass environmental issues, as noted in the ISO 26000 standards. Thus, it is now usual to find companies and researchers using the term "Social-Environmental Responsibility" - SER (AMARAL; MARSON, 2013; NASCIMENTO; LEMOS; MELLO, 2008). In this article, we consider that the CSR term also includes the concern for environmental issues, thus justifying the option for using the term SER (Social-Environmental Responsibility) throughout the text. A single exception occurred in study 2, when we used the term CSR to maintain consistency with the methodology proposed by Heger (2007). Still, one must understand that this term embeds both social as environmental and ethical concerns.

A large number of organizations conducts and maintains social and environmental projects. Amongst the medium and large enterprises, it is increasingly difficult to find one that has made no investment in corporate social responsibility and environmental management (NASCIMENTO; LEMOS; MELLO, 2008; WAJNBERG; LEMME, 2009). Advancing on the theme, Hrdlicka and Kruglianskas (2010) identified that, during 2008 global financial crisis, companies commited to sustainability and that applied their principles in business strategy achieved better results than their competitors who did not. Savitz and Weber (2006) also found out intangible benefits that sustainable companies can take advantage of, such as reputation improvement, greater satisfaction among their employees and willingness among their customers.

\subsection{Attraction and Retention of Human Capital}

With reference to the Resource-Based View (BARNEY, 1991), researchers have suggested that attracting and retaining human capital can offer companies an important strategic advantage (PLOYHART, 2004; PLOYHART; MOLITERNO, 2011). The company attractiveness brings more qualified candidates, allowing greater selectivity in hiring employees. It is especially critical when additional challenges restrict the acquisition of human capital, essential to ensure the productivity of enterprises. An example of this occurs when demographic, economic and political factors limit the number of qualified workers in the labor market (SOMAYA et al., 2008). On the other hand, the ability to retain competent and engaged employees requires the company to maintain essential knowledge and reduces the cost of staff turnover and replacement (BRYMER et al. 2014). Moreover, it is particularly advantageous in light of a workforce with greater expectations, less interested in bonding and more intolerant to frustration (DEAL et al., 2010; CAVAZOTTE; LEMOS; VIANA, 2012).

With respect to the type of employees, the knowledge accumulated in the recruitment field has supported HR professionals in developing strategies and policies that leverage the attractiveness of their companies. Models and theories point to some critical factors of attractiveness, such as 
characteristics of recruiters, reactions to the selection process and available job alternatives, but emphasize the importance of perceived work and organizational characteristics (CHAPMAN et al., 2005). Among them, the organizations' context and image appear as the most relevant in the literature on attraction of new employees (CHAPMAN et al., 2005).

Marketing researchers are also interested in company attractiveness and apply the concepts of advertising and brand management to the issue, based on the principle that employees and the positions they hold are equal to costumer and internal products of the organization respectively. In this field, the concept of attractiveness is defined as "the expected benefit by a potential employee from working for a specific company" (BETHON, et al., 2005, p.156). Studies have shown that initial images of an individual regarding attributes of an enterprise (e.g.: innovative, competent company) impact the attractiveness of the organization as much as instrumental aspects associated with what these employers do (e.g.: salary, flexible working hours and job security) (e.g.: LIEVENS; HIGHHOUSE, 2003). These effects depend on the importance of belonging to groups in the formation of self-concept and social identity of an individual (ASHFORTH; MAEL, 1996). A company that builds its reputation around attributes that have symbolic importance for the individual and their reference group exert greater attractive force on that person.

With regards to employee retention, the ability of companies to keep their employees is directly associated with low turnover. The turnover in a company is defined by the ratio between admissions and dismissals of professional, voluntarily or involuntarily, in a given period. The higher the turnover rate in a company, the greater the handling of staff. Voluntary turnover is the employee's decision to terminate the employment relationship through resignation (MITCHELL et al, 2001). This turnover is not interesting for employers, as it results in tangible and intangible costs to the company. Costs related to the employee's breach of contract (registration and documentation) add to the cost of hiring and training replacement. Additionally, there may be loss of know-how and transfer of knowledge to competitors.

Factors associated with the working environment can lead to staff turnover by creating tensions that stimulate the desire for change in the individual (HANCOKE et al., 2012). These factors influence positive or negative experiences at work, consequently affecting employee satisfaction. Thus, it is portrayed as a central reason for resigning. When the employee is dissatisfied, they seek two possible alternatives: the search for new market opportunities to exit the current job, or the search for an internal transference that could improve their satisfaction - if the search result is satisfactory in eliminating the nuisance, the relationship with the company would continue (STEEL; LOUNSBURY, 2009).

Some HR practices are highly effective in generating greater satisfaction and commitment among employees, reducing turnover rates. The most frequent are tangible incentives (e.g., salary, 
benefits), indirect investments (training opportunities), internal mobility and work structures that increase employee participation (HEAVEY; HOLWERDA; HAUSKNECHT, 2013). Absence of these practices may cause the employee exit. Besides, interpersonal relationships stand out as relevant at work, both among employees and between them and their managers. Companies that do not pay attention to these factors may lose employees and, as a direct consequence, have reduced organizational effectiveness.

\subsection{SER's role in the attraction and retention of employees}

The success of SER in a company seems to depend on the ability to integrate social and environmental goals to the organization's operations (WEYBRECHT, 2010). In this sense, the human resource strategies should be in line with their culture and values related to sustainability, to better support the delivery of sustainable returns to investors, to ensure the fulfillment of customer needs, and respond to emerging social trends and regulation (WBCSD, 2008). Referring to the role of the HR department in relation to sustainability driven strategies. Bullara (2003) states that socially responsible companies are not limited to creating social projects and being active in this sphere, but they are also proactive in educating and raising awareness of its employees to promote a socially responsible environment.

Thus, the Human Resources area would be essential for a responsible and sustainable management, for it would create the engagement of the workforce and foster an environment where SER is present in all aspects of the employee's cycle in the company. To this end, it would be necessary to align the organizations's key systems and processes with the human resources activities such as managing change, competence development, support to commitment, talent and diversity management, recruitment, among others (WEYBRECHT, 2010). On the other hand, while promoting institutional gains, due to the improvement of the company's relationship with its various stakeholders, SER favors human resource management, particularly, in acting as an attractiveness factor on potential employees and a retention factor on their workforce.

Although there are many reasons that help explaining why people are attracted to a company, contemporary thinking on people management has suggested that an applicant does not decide to approach an organization purely for the financial rewards offered. Literature suggests that other types of intangible benefits can make a company more attractive before their competitors (BOHLANDER; SNELL; SHERMAN, 2010). By using an American database, which evaluates and ranks companies according to their social responsibility practices (KINDER; LYDENHERG; DOMINI \& CO.- KLD), Turban and Grening (1997) tested and confirmed the hypothesis that, regardless of the corporate performance, the social responsibility of a company is associated with its reputation and attractiveness for university students. 
In Brazil, the results of a research conducted with young undergraduate students also suggest that the corporate social responsibility efforts can help recruit new talent, by working as an attractiveness factor similar to other types of benefits, such as compensation, image and the possibility of professional development (FARIA; FERREIRA; CARVALHO, 2012; CAVAZOTTE; LEMOS; VIANA, 2012). Thus, this research investigates the following hypothesis:

$\mathrm{H} 1$ - The perception that a company is socially and environmentally responsible is positively associated with the attractiveness of the company on potential employees.

In addition to promoting the attractiveness of potential employees before the external public, daily practices of a company's SER would also have the potential to generate greater productivity in the internal environment, promoting greater motivation, self-esteem and pride among employees (MELO NETO; FRÓES, 2001). Thus, if on the one hand SER is effective only when there is adequate awareness and training of employees on the subject, on the other, the employees' finding that the company is practicing it and that those actions also bring them benefits would increase the company's retention potential (Melo Neto; Fróes, 2001; Jones, 2010).

In Brazil, some companies are already aware of the importance of investing in social responsibility focused on its internal audience to build solid bridges of empathy with its employees (PARENTE et al., 2013). However, this requires SER discourse and practice to be in accordance. (RABELO; SILVA, 2011). Thus, while SER is considered as a potential competitive advantage (FARIA; FERREIRA; CARVALHO, 2012), its effective practice can act as a retention factor of skilled labor (e.g.: BRAMMER; PAVELIN, 2006; GLAVA; PRIDERIT, 2009). Thus, based on the literature, this research also investigates the following hypothesis:

$\mathrm{H} 2$ - The perception that a company is socially and environmentally responsible is positively associated with employee retention.

In order to contribute to the advancement of empirical research on the implications of SER for strategic management and expansion of human capital of enterprises, this paper presents the results of two studies, the first focused on the attraction and the second on the retention of young professionals.

\section{STUDY 1 - INVESTIGATING SER AS AN ATTRACTION FACTOR (EXPERIMENT)}

The first study aims to identify whether the practice of social and environmental responsibility by a company is a factor of attraction for Business Administration undergraduate students. As we are dealing with a controlled experiment followed by a quantitative treatment, four specific hypotheses were formulated:

H1a: On considering a company that pays wages and offers career opportunities and professional development according to market average, positive information on its social- 
environmental responsibility practices make it more attractive than if there is no information on these practices.

H1b: On considering a company that pays wages and offers career opportunities and professional development according to market average, positive information on its socialenvironmental responsibility practices make it more attractive than if there is negative information on these practices.

H1c: A company that pays wages and offers career opportunities and professional development according to market average, but with positive information on its social-environmental responsibility practices, is more attractive than one that pays wages and offers career opportunities and professional development above the market average, but with negative information on its social and environmental responsibility practices.

$\mathrm{H1d}$ : A company that pays wages and offers career opportunities and professional development below market average, but with positive information on its social-environmental responsibility practices, is more attractive than one that pays wages and offers career opportunities and professional development above the market average, but with negative information on its social and environmental responsibility practices.

\subsection{Study 1 Methodological Procedure}

The study was initially based on research by Faria, Ferreira and Carvalho (2012), which reports on a controlled experiment conducted in 2007 with undergraduate students from two universities, located in Rio de Janeiro. The study sought to identify whether the practice of corporate social responsibility would be a relevant factor of attractiveness for the sampled students. In our study, for ease of access issues, we restricted the sample to Administration undergraduate students from a single private university of Rio de Janeiro. In addition, the study by Faria, Ferreira and Carvalho (2012) was partially modified to the specific objectives, the content of the experiment and research hypotheses. In our study, each participant in the experiment was subjected to a scenario where two factors (independent variables) were manipulated:

Factor 1 - "Human Resources Policy", containing information on salary payments, career and professional development policies of a hypothetical company $\mathrm{X}$, usually sought by young people when considering job offers from companies. The factor was presented in three levels: above the market average, equal to the market average and below the market average. 
Factor 2 - "Social-Environmental Responsibility Policy (SER)", containing information on the company's SER practices. This factor was also presented at three levels, by placing a sentence about the practices of the company X: the company operates with Social-Environmental Responsibility, without Social-Environmental Responsibility, and without any information about their SER practices, constituting a control group.

The combination of these two factors, each with three levels, result in nine possible groups, although in this study, we only used the five scenarios needed to test the hypotheses presented (Figure 1).

The experiment consists of the following: By accessing the questionnaire in the Qualtrics program on the Internet, the respondent read one of the five scenarios in Figure 1, which was randomly assigned by the software itself. Based on the scenario information, the participant answered four statements based on the study by Faria, Ferreira and Carvalho (2012), to evaluate the construct "Company's Attractiveness", by using the Likert scale ranging from 1 ("Totally disagree") to 5 ("Totally agree"). An example of statement used "I would very much like to work at the company $X$ ". Then we computed the dependent variable "General_Attractiveness" from the means calculated for the four statements comprising the construct "Company's Attractiveness".

We selected the respondents by the accessibility criterion, having been enrolled from We selected the respondents for each of the eight periods of the business course, resulting in a total of 177 participants. We estimate that this number represents $14.8 \%$ of the researched universe. After cleaning the database, excluding questionnaires with filling up errors and identifying outliers, with filling up errors and identifying outliers, with the following distribution: Group 1: $\mathrm{n}=32$, Group 2: $n=29$, Group 3: $n=30$, Group 4: $n=30$, and Group 5: $n=33$. The resulting data were then analyzed using the statistical PASW 18.0 software (by SPSS).

\subsection{Sample of study 1}

Most of the sample's respondents $49.1 \%$ are between 21 to 25 years old, followed by $26.5 \%$ who are between the ages of 17 and 20 years, and $17.4 \%$ above 26 years. Out of the 154

\begin{tabular}{|c|c|c|}
\hline Scenarios/Groups & Social-Environmental Responsibility Policy & Human Resources Policy \\
\hline Scenario/Group 1 & No information & Market average \\
\hline Scenario/Group 2 & High Responsibility & Market average \\
\hline Scenario/Group 3 & High Responsibility & Below Market average \\
\hline Scenario/Group 4 & Low Responsibility & Market average \\
\hline Scenario/Group 5 & Low Responsibility & Above Market average \\
\hline
\end{tabular}

Source: Authors.

Figure 1. Scenarios: Social-Environmental Responsibility Policy x Human Resources Policy. 
respondents, $61 \%$ were female and $39 \%$ male. About $60 \%$ of students attend from the 5 th to the 8 th semester, of which $53 \%$ had already been exposed systematically to the theme of Corporate Social Responsibility through a compulsory class offered in the 5th period. The others had already received basic information on the theme in the Introduction to Management subject. Individually, students from the 5 th $(21.3 \%)$ and $6^{\circ}(17.4 \%)$ semester were the majority in the sample. Most of the respondents (41.3\%) study only, followed by $34.2 \%$ also attending internships, $18.7 \%$ already employed and 5.8\% who act as entrepreneurs.

\subsection{Presentation and Analysis of Results of Study 1}

In Table 1, we present the mean and standard deviation observed for the variable General_ Attractiveness in each group.

With the help of the Kolmogorov-Smirnov test we observed that the distribution of the variable General_Attractiveness was not normal, However, we consider the ANOVA to be a very robust test when the normality assumption of data is not met (MCCLAVE; BENSON; SINCIC, 2008). By using Levene's Test we observed that the original four dependent variables and the resulting variable General_Attractiveness (MCCLAVE; BENSON; SINCICH, 2008) met the assumption of homogeneity of variances. Since this last assumption was confirmed, we proceeded to use the One-Way ANOVA test to analyze whether there was a statistically significant difference between two or more population means (CORRAR et al., 2012).

Analysis of variance aimed to verify if there was a significant difference between the means of the 5 groups (corresponding to the 5 scenarios) for the variable General_Attractiveness. As shown in Table 2, the F-statistic in ANOVA $(F=20.34)$ presented a significance level lower than $0.05(p<0.00)$, and thus the null hypothesis of equality between the 5 groups was rejected.

To test the hypotheses $\mathrm{H} 1 \mathrm{a}$ and $\mathrm{H} 1 \mathrm{~b}$, we needed to compare the means of the variable General_Attractiveness between the groups 1, 2 and 4. By applying Bonferroni's test, we reached the following results, shown in Table 3.

As can be seen in Table 3, for groups 1 and 2, whose scenarios involve companies that have the same human resources policies (at the market average), we could not verify, at a 0.05 significance level, that the mean of variable General_Attractiveness of group 2 (High SER) is greater than that of group 1 (without information on SER) $(p=0.52)$, although it appears to be higher (4.28 against 3.79). Thus, hypothesis H1a was rejected. On the other hand, the mean of the variable General_Attractiveness of group 2 (High SER) statistically higher result than that of group 4 (Low SER) $(p<0.000)$, and hypothesis H1b was not rejected.

To test hypothesis H1c, we needed to compare the means of the variable General_Attractiveness between the groups 2 and 5. By applying Bonferroni's test, we verified that the mean of the variable 
Table 1. Mean and Standard Deviation of the Variable General Attractiveness.

\begin{tabular}{ccccccc}
\hline $\begin{array}{c}\text { General__ } \\
\begin{array}{c}\text { Attractiveness for the } \\
5 \text { groups }\end{array}\end{array}$ & $\begin{array}{c}\text { Factor 1 - } \\
\text { Social-Environmental } \\
\text { Responsibility Policy }\end{array}$ & $\begin{array}{c}\text { Factor 2 - Human } \\
\text { Resources Policy }\end{array}$ & $\mathrm{N}$ & Mean & Sdt. Dev. & Sdt. Dev. \\
\hline 1 & No information & Market Average & 32 & 3.79 & 0.87 & 0.15 \\
\hline 2 & High Responsibility & Market Average & 29 & 4.28 & 0.80 & 0.15 \\
\hline 3 & High Responsibility & $\begin{array}{c}\text { Below Market } \\
\text { Average }\end{array}$ & 30 & 3.03 & 1.08 & 0.20 \\
\hline 4 & Low Responsibility & Market Average & 30 & 2.17 & 1.02 & 0.19 \\
\hline 5 & Low Responsibility & $\begin{array}{c}\text { Above Market } \\
\text { Average }\end{array}$ & 33 & 3.00 & 1.11 & 0.19 \\
\hline Total & & & 154 & & & \\
\hline
\end{tabular}

Source: Authors - PASW Statistics 18 (SPSS).

General_Attractiveness of group 2 (High SER and HR Policy at average) is statistically higher than that of group 5 (Low SER and HR Policy above average) $(p<0.00)$. Thus, hypothesis H1c was not rejected.

Finally, to test hypothesis H1d we compared the means of the variable General_Attractiveness between groups 3 and 5. By applying Bonferroni's test, we reached the results seen in Table 3 (difference of 0.03 in favor of group 3). Since the mean of the variable General_Attractiveness of group 3 (High SER and HR Policy below average) it is not statistically higher than that of group 5 (Low SER with HR Policy above average) ( $p=1.00)$, hypothesis H1d was rejected.

\section{STUDY 2 - INVESTIGATING CSR AS A RETENTION FACTOR (SURVEY)}

Trainee programs are strategies to attract qualified young professionals with high-potential. In the structure of enterprises, the trainee is generally a post-internship position, occupied by undergraduate students in the last year of college or recent graduates, who undergo an intensive training period and receive considerable investments from the company in order to accelerate the acquisition of skills required in their subsequent positions. These programs make use of rigorous selection processes to identify the most promising applicants in terms of qualification and profile. However, experts report a loss of up to $50 \%$ of trainees due to voluntary turnover even before

Table 2. ANOVA for the variable General_Attractiveness.

\begin{tabular}{lccccc}
\hline & & Sum of Squares & df & F & Significance $p$ \\
\hline \multirow{3}{*}{ General_Attractiveness } & Amongst Groups & 79.01 & 4 & 20.34 & 0.00 \\
& Within Groups & 144.74 & 149 & & \\
& Total & 223.75 & 153 & & \\
\hline
\end{tabular}

Source: Authors - PASW Statistics 18 (SPSS). 
Table 3. Bonferroni's test for the hypotheses of the study.

\begin{tabular}{cccccc}
\hline $\begin{array}{c}\text { Reference } \\
\text { Group (i) }\end{array}$ & $\begin{array}{c}\text { Comparison } \\
\text { Group (j) }\end{array}$ & $\begin{array}{c}\text { Tested } \\
\text { hypothesis }\end{array}$ & $\begin{array}{c}\text { Difference } \\
\text { between means (i-j) }\end{array}$ & Standard error & $\begin{array}{c}\text { Significance of } \\
\text { the test } p\end{array}$ \\
\hline 2 & 1 & H1a & 0.49 & 0.25 & 0.53 \\
2 & 4 & H1b & 2.12 & 0.26 & 0.00 \\
2 & 5 & H1c & 1.28 & 0.25 & 0.00 \\
3 & 5 & H1d & 0.03 & 0.25 & 1.00 \\
\hline
\end{tabular}

Source: Authors - PASW Statistics 18 (SPSS).

they begin to bring results (SANTOS, 2013). This study was conducted to evaluate the second hypothesis hypothesis, i.e. the relationship between CSR and voluntary turnover among trainees.

\subsection{Methodological Procedure of Study 2}

The study was conducted with young professionals who participated in trainee programs after being chosen in selection processes coordinated by specialized consultants. Access to participants occurred from the database of a recruitment company that performs such processes on behalf of various organizations, where we selected potential participants among registered individuals who were: 1) applicants in trainees selection processes for companies of Rio de Janeiro and São Paulo, 2) identified as suitable by recruiters, and 3) hired as trainees by companies for a minimum of one and up to five years. An email was sent to the resulting list, with the invitation to participate in the research and the access link to an electronic questionnaire. The email informed potential participants that the available data would allow the recruitment company to survey perceptions and expectations of these professionals on their employers and align them to new opportunities in the labor market, and that the answers would be treated as confidential and only accessed by analysts involved in the survey.

For control purposes, the questionnaire included questions regarding the participants demographic profile (age, gender and marital status) and two inventories of personality traits associated with turnover: emotional stability and conscientiousness (GOLDBERG, 1990), both answered through a five-point Likert scale. Following on, the survey inquired about the characteristics of the organization where the participant took part in the trainee program, its size and operating segment, and requested them to evaluate the company in five areas relating to the attributes of employers (Employment Value Proposition) (HEGER, 2007). Three items evaluated the rewards (i. salary; ii. benefits; iii. recognition/meritocracy), two items the opportunities (i. training; ii. career), three items the organization (i. good image; ii. Commitment to CSR/Ethic; iii. company culture), four items the work (i. impact; ii. location; iii. balance personal/professional life; 
iv. alignment with work interests), and two evaluated the people (i. environment; ii. management/ leadership quality). Responses were given through a five point scale, ranging from 1 "very bad, bad" to 5 "excellent, very good". Finally, the questionnaire asked the participants to report whether they still remained in the company in which the program took place, and if otherwise, the reasons that led to leaving the company: voluntary resignation (to seize another opportunity or the lack of interest in staying in the company) and involuntary dismissal (due to vacancies restriction for hiring or contract being cancelled by the company).

\subsection{Sample of Study 2}

Participants with incomplete questionnaires were excluded from the analysis, as well as those who indicated having left the company involuntarily due to restriction of hiring vacancies and who had contracts cancelled by the company. The final sample totaled 95 professionals, of which $62.1 \%$ are still working in companies that hired them as trainees, and $37.9 \%$ had voluntarily left the company. Among the participants, 58\% are male, with mean age of 29 years, $75 \%$ were single. Regarding the level of education, $41 \%$ have completed higher education, and $42 \%$ have lato sensu post-graduations. More than $80 \%$ reported having done the trainee program at a large company.

\subsection{Presentation and Analysis of Results of Study 2}

Initially, we performed an analysis of variance (ANOVA) to observe significant differences between the group who remained and the group who voluntarily left the companies in the evaluation of the 14 employers' attributes (Table 4).

The result of this analysis indicated significant differences in the evaluation of seven of the attributes: salary, CSR/ethic, work impact, growth opportunities, work environment, alignment with an area of interest and balanced private life. Table 5 presents the means, standard deviation and correlation coefficients between these seven attributes, the participant's personality traits and the decision to leave the company. We can observe that there are significant correlations between some of the attributes assessed.

In order to identify the unique contribution of each attribute in the decision to leave the company, following on we performed a logistic regression analysis. In this regression, the criterion of interest is the decision to leave the company, with a dummy variable with value 0 for those who remained and 1 for those who left. As control variables, we included the demographic characteristics of participants, gender $(0=$ female, $1=$ male $)$ and age, and the indices observed for the personality traits conscientiousness and emotional stability. Given the high correlations 
observed in the previous analysis between the employer's attributes, we included in the model only the four employer attributes for which there was a difference greater than 0.55 in the ANOVA, i.e., salary, CSR/ethics, growth and alignment with work interests, in order to assess their unique contribution and relative importance in the participant's likelihood to leave the company in which he or she took part in the trainee program, thus minimizing multicollinearity in the tested model.

The result of the analysis (Table 6) showed a significant omnibus index $\left(\chi^{2}=31.81 p<0,001\right.$; -2 loglikelihood $=90.41$; Cox\&Snell $\mathrm{R}^{2}=0.29$; Negelkerke $\mathrm{R}^{2}=0.40$ ). The model explained between 29 and $40 \%$ of the decision to leave the company, and according to the classification matrix, the percentage of correct classification of cases was $70.7 \%$. In the analyzed group, personality factors were not determinant in the decision to leave, nor the participant's gender. However, the results of the analysis indicated that the individual variable age (Wald $=7.47$, $p<0.01)$ and the organizational variables CSR/ethics (Wald $=4.92, p<0.05$ ) and salary/bonus (Wald $=3.84, p<0.05$ ) are significantly associated with the decision to leave the company (Table $5)$. The older the participant, the more likely they were of having left the company $\left(\beta=0.28 ; e^{\beta}=\right.$ 1.32). Furthermore, the probability of leaving the company was also higher for the former trainees who evaluated more negatively the organizational attributes salary $\left(\beta=-0.59 ; e^{\beta}=0.55\right)$ and CSR $\left(\beta=-0.67 ; e^{\beta}=0.51\right)$.

Table 4. ANOVA: Employers' Attributes.

\begin{tabular}{lccc}
\hline \multicolumn{4}{c}{ Differences between groups with and without turnover } \\
\hline Area & T Test & $p$ value & Difference \\
Benefits & 0.51 & 0.61 & 0.14 \\
Training & 0.99 & 0.32 & 0.26 \\
Recognition & 1.43 & 0.16 & 0.37 \\
Image & 0.12 & 0.90 & 0.03 \\
Environment & $2.21^{*}$ & 0.03 & 0.48 \\
Salary & $2.80^{* *}$ & 0.01 & 0.64 \\
Growth & $2.25^{*}$ & 0.03 & 0.55 \\
CSR/ethic & $2.54^{* *}$ & 0.01 & 0.60 \\
Impact & $2.33^{*}$ & 0.02 & 0.50 \\
Location & 0.66 & 0.51 & 0.19 \\
Culture & 1.99 & 0.06 & 0.46 \\
Balance & $2.05^{*}$ & 0.04 & 0.51 \\
Management & 1.49 & 0.14 & 0.38 \\
Alignment & $2.14^{*}$ & 0.04 & 0.55 \\
\hline Not $p<0.05 ; * p$ & & &
\end{tabular}

Note: $* p<0.05 ; * * p<0.01$.

Source: Authors - PASW Statistics 18 (SPSS). 
Table 5. Correlation Table.

\begin{tabular}{|c|c|c|c|c|c|c|c|c|c|c|c|}
\hline \multicolumn{12}{|c|}{ Correlations } \\
\hline & Mean & SD & 1 & 2 & 3 & 4 & 5 & 6 & 7 & 8 & 9 \\
\hline 1. Environment & 3.39 & 1.04 & & & & & & & & & \\
\hline 2. Salary & 3.06 & 1.12 & $0.30 * *$ & & & & & & & & \\
\hline 3. Growth & 3.23 & 1.17 & $0.41 * *$ & $0.46^{* *}$ & & & & & & & \\
\hline 4. CSR/ethic & 3.46 & 1.14 & $0.62 * *$ & 0.08 & $0.41 * *$ & & & & & & \\
\hline 5. Impact & 3.40 & 1.03 & $0.53 * *$ & $0.25 *$ & $0.53 * *$ & $0.54 * *$ & & & & & \\
\hline 6. Balance & 2.86 & 1.18 & $0.30 * *$ & $0.32 * *$ & 0.12 & $0.31 * *$ & 0.17 & & & & \\
\hline 7. Alignment & 3.20 & 1.22 & $0.50 * *$ & $0.36^{* *}$ & $0.36^{* *}$ & $0.42 * *$ & $0.51 * *$ & $0.42 * *$ & & & \\
\hline 8. Consciousness & 4.09 & 0.55 & 0.17 & -0.08 & 0.05 & 0.15 & 0.05 & 0.00 & 0.09 & & \\
\hline 9. Stability & 3.58 & 0.55 & 0.12 & 0.11 & -0.12 & 0.09 & -0.15 & 0.04 & 0.14 & $0.25^{*}$ & \\
\hline 10. Exits & 1.37 & 0.48 & $-0.22 *$ & $-0.28 *$ & $-0.23 *$ & $-0.26^{*}$ & $-0.24 *$ & $-0.21 *$ & $-0.22 *$ & 0.19 & 0.04 \\
\hline
\end{tabular}

\section{DISCUSSION AND CONCLUSIONS}

This study aimed to investigate the influence of social-environmental responsibility of companies on their potential to attract and retain young professionals, taking into account different contextual factors that influence working conditions.

The results of the first study, of an experimental nature, indicate that CSR may already be playing a role in attracting young talent, even if it is not the main attractiveness factor in businesses. University students who participated in the experiment showed a preference for more socially and environmentally responsible companies, when practiced Human Resources policies are at the market average. The results also suggest that negative information on CSR can jeopardize the image of a company to the extent that it exerts lesser attraction on young professionals, even if its human resources policies are better than the market average. However, the results indicate that the concerns of young people with respect to human resource policies remain relevant, suggesting that that promoting social-environmental actions is not enough for a company to be able to attract young professionals if there is no investment being done on employees.

Thus, this research confirms the findings of recent studies in Brazil by Faria, Ferreira and Carvalho (2012) and Amaral and Marson (2013), indicating that SER is a relevant factor in the choice of the first job or the one following it by young Brazilians, although this influence depends on other contextual factors associated with the practiced HR policies. The use of the experimental method in this study allows us to establish a cause and effect relationship between the studied variables variables. It is worth noting, however, that due to the nature of the experiment conducted, we are unable to establish a direct relationship between the degree of attractiveness declared by 
Table 6. Logistic Regression

\begin{tabular}{lcccccc}
\hline Predictors & $\mathrm{B}$ & $\mathrm{EP} \beta$ & Wald & $\mathrm{df}$ & $p$ value & $\mathrm{e}^{\beta}$ \\
\hline Constant & -9.58 & 3.96 & 5.86 & 1.00 & 0.02 & 0.00 \\
Age & 0.28 & 0.10 & $7.47^{*}$ & 1.00 & 0.01 & 1.32 \\
Gender $(0=$ fem; $1=$ male $)$ & 0.18 & 0.54 & 0.12 & 1.00 & 0.73 & 1.20 \\
Conscientiousness & 0.78 & 0.55 & 2.04 & 1.00 & 0.15 & 2.18 \\
Emotional Stability & 0.59 & 0.53 & 1.25 & 1.00 & 0.26 & 1.80 \\
Salary & -0.59 & 0.30 & $3.84^{*}$ & 1.00 & 0.05 & 0.55 \\
CSR & -0.67 & 0.30 & $4.92^{*}$ & 1.00 & 0.03 & 0.51 \\
Growth & -0.08 & 0.30 & 0.07 & 1.00 & 0.80 & 0.93 \\
Alignment & -0.04 & 0.25 & 0.03 & 1.00 & 0.87 & 0.96 \\
\hline Tests & $\chi^{2}$ & $\mathrm{df}$ & $p$ value & & & \\
\hline Model Evaluation & & & & & & \\
Omnibus & 31.81 & 8 & 0 & & & \\
Log likelihood-2 & 90.41 & & & & & \\
Goodness-of-fit & & & & & & \\
Hosmer and Lemeshow & 9.53 & 8 & 0.3 & & & \\
$\mathrm{R}^{2}$ Cox \& Snell & 0.29 & & & & & \\
$\mathrm{R}^{2}$ Nagelkerke & 0.40 & & & & & \\
\hline
\end{tabular}

Source: Authors - PASW Statistics 18 (SPSS).

participants and their actual choices in recruitment and selection processes. Only future studies can verify this point.

Similarly, the results of the second study suggest that social/ethical responsibility attributed by these trainees to the companies where they worked is statistically associated with the likelihood of them having left the company voluntarily, regardless of their satisfaction with salary, growth opportunities and alignment of interests with the work performed. Although satisfaction with the practiced salary also influenced the decision of former trainees to leave the company, CSR had an impact of similar magnitude. This observation confirms the premise of several authors on the potential impact of corporate social responsibility in the retention of human capital (e.g.: GLAVAS; PRIDERIT, 2009; JONES, 2010) and contributes to advancing research on CSR and voluntary turnover by identifying its importance vis-à-vis other working conditions present in companies.

However, given that participation in the survey was voluntary, we cannot rule out the possibility that this research group has a particular characteristic that makes CSR more relevant for them than for other groups. In order to limit this possibility, the study included as control variables some personality traits associated with different behaviors at work (BARRICK; MOUNT, 2009). It is possible that other individual differences not controlled for but associated with this trend might predominate among these participants. However, since the alignment of employees with the CSR culture of a company seems to be strategically important to ensure a more solid performance 
in terms of corporate citizenship (WEYBRECHT,2010), the retention of people who are more sensitive to these issues would be particularly interesting.

In summary, this work contributes to the understanding of social and environmental responsibility and human resources management in organizations, especially with regard to the relative role of the former in drawing and binding intellectual capital to companies. From a theoretical point of view, the study advances the proposition that social responsibility nowadays has become an important element in the evaluation of companies for the new generation, with a significant impact on converging and creating links with these employees, but this influence depends on other organizational practices, such as the salary policy and other working conditions in companies.

More specifically, the first study contributes to the literature by proposing and verifying that young professionals nowadays are attracted not only by potential personal and professionals gains, but also by the environmental behavior of companies in which they seek employment. However, the results of the experiment also suggest that there are limits to the influence that CSR has on choosing an enterprise: it is relevant when HR policies are at least at the market's average, but it is not strong enough to compensate for HR policies below the market average. The second study contributes to the literature by verifying that the company CSR perceived by a young employee influences he/she likelihood to leave the company as much as the HR policies adopted by the organization, particularly the salary levels that are practiced. In this sense, the study also observes that it is not sufficient for a company to only seem responsible; it is necessary that their practices reflect such concerns so that it can maintain its intellectual capital, regardless of the satisfaction level of young employees with their personal and professional gains in the company.

\subsection{Suggestions for Future Research and Firms' Practice}

Our suggestion for future studies is to further investigate whether social responsibility practices with different focuses, i.e., targeted at different stakeholders, are also associated with attracting and retaining employees. In addition por Similarly, new studies could investigate the influence of these practices on attitudes, engagement and employee productivity. In addition, new studies could also investigate the influence of SER practices on attitudes engagement and employee productivity. For example, one could also evaluate whether employees who actively participate in SER voluntary actions are more productive and motivated in their daily tasks than others. Future studies, using a longitudinal approach, can also analyze the role of leaderships as agents in building and reproducing principles of social responsibility along with employees, and its impact on voluntary turnover. Finally, we suggest for future research on the subject to merge qualitative and quantitative approaches. In-depth interviews with applicants, employees and other stakeholders can help identify more clearly which components of SER practices positively affect 
these groups the most and increase their propensity to join or stay in the business, complementing and enriching the data and quantitative analyses.

In addition to the implications for the research of SER as a factor in attracting and retaining young professionals, this study also presents practical contributions. The results indicate that factors associated with attracting and retaining young professionals go beyond monetary issues. Thus, companies that regard the retention of intellectual capital as a strategic objective must be aware of their image before its employees, seeking to develop practices associated with ethical principles and social responsibility among their functional and managerial staff, in order to strengthen this internal culture at all levels of decision making in the company.

Investment in SER actions in companies together with their communication on recruitment campaigns seem to be important initiatives to increase the attraction of the best talents and to retain new generations of professionals. Therefore, in addition to disclosing information on human resource practices, SER initiatives and policies should also be widely reported to internal and external audiences. It is clear, however, that the cost may be high for companies that are immature in corporate citizenship or which propagandize actions not consistent with their practices. Therefore, in ideal terms, we expect that the results of this study encourage companies that want to improve their SER programs to work in this direction, as a measure to also expand their intellectual capital, reduce the loss of talent and minimize the costs associated with the turnover of young employees.

\section{REFERENCES}

ALBINGER, H. S.; FREEMAN, S. J. Corporate Social Performance and Attractiveness as an Employer to Different Job Seeking Populations. Journal of Business Ethics 28: 243-253, 2000.

AMARAL, R. M. P.; MARSON, L. S. C. A Percepção da Responsabilidade Social Corporativa como Fator de Atração e Retenção de Talentos. Anais do IX Congresso Nacional de Excelência em Gestão de Talentos. 2013. Disponível em: <http://www.excelenciaemgestao.org/Portals/2/ documents/cneg9/anais/T13_0621_3417.pdf> Acesso em: 9 de setembro de 2014.

ARORA, N.; HENDERSON, T. Embedded premium promotion: Why it works and how to make it more effective. Marketing Science, 26: 514-531, 2007.

ASHFORTH, B. E.; MAEL, F. Organizational identity and strategy as a context for the individual. In: J. A. C. Baum \& J. E. Dutton (Eds.). Advances in Strategic Management. Greenwich, CT: JAI Press, v.13, p.19-64, 1996.

AZEVEDO, A. L.V. Indicadores de sustentabilidade empresarial no Brasil: uma avaliação do relatório do CEBDS. Revista Ibero americana de Economia Ecológica, v. 5, p. 75-93, 2011.

BARNEY, J. B. Firm resources and sustained competitive advantage. Journal of Management, 17, 771-792, 1991.

BARRICK, M. R.; MOUNT, M. K. Select on Conscientiousness and Emotional Stability. E. A. Locke (Ed.), Handbook of Principles of Organizational Behavior, 15-28, 2nd ed. Blackwell Publishers,2009. 
BERTHON, P.; EWING M.J.; HAH, L.L. Captivating Company: Dimensions of Attractiveness in Employer Branding, International Journal of Advertising, 24(2), pp.151-172, 2005.

BOHLANDER, G.; SNELL, S.; SHERMAN, A. Administração de recursos humanos. São Paulo: Pioneira Thomson Learning, 2005.

BORGES, S.; DUBEUX, V. J.; PEREIRA, C. A. A teoria na prática é outra': os conhecimentos sobre meio ambiente e as práticas sustentáveis de universitários cariocas. In: Lívia Barbosa. (Org.). Juventudes e Gerações no Brasil Contemporâneo. 1ed. Porto Alegre: Editora Sulina, p. 159-180, 2012.

BRAMMER, S. J.; PAVELIN, S. Corporate reputation and social performance: The importance of fit. Journal of Management Studies, 43, 435-455, 2006.

BRYMER, R.; MOLLOY, J.; GILBERT, B. Human Capital Pipelines: Competitive Implications of Repeated Interorganizational Hiring. Journal of Management, 40(2): 483-508, 2014. Disponível em: <http://jom.sagepub.com/content/39/3/573>. Acesso em: 04 de março de 2014.

BUllarA, C. F. C. As Exigências de uma Política de Responsabilidade Social. In: Anais do VI Congresso Latino-Americano de Ética, Negócios e Economia. São Paulo, 2003.

CARROLL, A. B.The Pyramid of Corporate Social Responsibility: Toward the Moral Management of Organizational Stakeholders, Business Horizons 34(4), 39-48, 1991. Disponível em: <http:// www.sciencedirect.com/science/article/pii/000768139190005G $>$. Acesso em 20/12/15.

CAVAZOTTE, F.; LEMOS, A. H.; VIANA, M. Novas gerações no mercado de trabalho: expectativas renovadas ou antigos ideais?. Cadernos EBAPE, v. 10, n. 1,p. 162-180, 2012.

CHAPMAN, D.S.; UGGERSLEV, K.L.; CARROLL, S.A.; PIASENTIN, K.A.; JONES, D.A. Applicant attraction to organizations and job choice: a meta-analytic review of the correlates of recruiting outcomes. Journal of Applied Psychology, 90, pp. 928-944, 2005.

CORRAR, L. J.; PAULO, E.; FILHO, J. M. D. Análise Multivariada para os cursos de Administração, Ciências Contábeis e Economia. São Paulo. Editora Atlas S.A, 2012.

DEAL, J. J.; ALTMAN, D. G.; ROGELBERG, S. G. Millennials at Work: What We Know and What We Need to Do (If Anything). Journal of Business and Psychology, 25(2):191-199, 2010.

ELKINGTON J. Toward the sustainable corporation: win-win business strategies for sustainable development. California Management Review, v. 36, n. 2, p. 90-100, 1994.

FARIA, M. D; FERREIRA, D.; CARVALHO, J. L. O discurso da responsabilidade social atrai jovens talentos? Revista da Faculdade de Administração e Economia, v.4, n.1, 2012.

GLAVAS, A.; PIDERIT, S. K. How does doing good matter? Effects of corporate citizenship on employees. Journal of Corporate Citizenship, 36: 51-70, 2009.

GOLDBERG, L. R. An alternative "description of personality": The big-five factor structure. Journal of Personality and Social Psychology, 59, 1216-1229, 1990.

HAMMES, V. S; ARZABE, C.; RACHWAL, M. F. G.; PRIMAVESI, O. M. A. Empresa, meio ambiente e responsabilidade socioambiental - Educação ambiental para o desenvolvimento sustentável. 2 ${ }^{\mathrm{a}}$ Ed. Distrito Federal: Embrapa, 2012.

HEAVEY,A. L.; HOLWERDA, J. A.; HAUSKNECHT, J. P. Causes and Consequences of Collective Turnover: A Meta-Analytic Review. Journal of Applied Psychology, v.98, n.3, p. 412-453,2013. 
HEGER, B. K. Linking the employee value proposition (evp) to employee engagement and business outcomes: Preliminary findings for a linkage research pilot study. Organizational Development Journal, 25, 121-133, 2007.

HRDLICKA H.A.; KRUGLIANSKAS, I. Influência das práticas de gestão socioambiental na internacionalização de empresas brasileiras. In: Afonso Fleury. (Org.). Gestão empresarial para a internacionalização das empresas brasileiras. São Paulo: Editora Atlas, v. 1, p. 253-289, 2010.

JONES, D. A. Does serving the community also serve the company? Using organizational identification and social exchange theories to understand employee responses to a volunteerism programme. Journal of Occupational and Organizational Psychology, 83: 857-878, 2010.

LIEVENS, F.; HIGHHOUSE, S. The relation of instrumental and symbolic attributes to acompany's attractiveness as an employer. Personnel Psychology, 56, 75-102, 2003.

MCCLAVE, J.T.; BENSON, P. G.; SINCICH, T. Estatística para Administração e Economia. São Paulo: Pearson Prentice Hall, 10ª Edição, 2009.

MELO NETO, F. P.; FRÓES, C. Gestão de Responsabilidade Social Corporativa: o Caso Brasileiro. Rio de Janeiro, Editora Qualitymark, 2ª Edição, 2001.

MITCHELL, T.R.; HOLTOM, B.C.; LEE,T.W.; SABLYNSKI, C.J.; EREZ. M. Why People Stay: Using Job Embeddedness to Predict Voluntary Turnover. The Academyof Management Journal Vol. 44, No. 6 (Dec.), pp. 1102-1121, 2001.

NASCIMENTO, L.F.; LEMOS, A.D. DA CUNHA; MELLO, M.C. Gestão Socioambiental Estratégica. Porto Alegre: Bookman, 2008.

PLOYHART, R. E. Organizational staffing: A multilevel review, synthesis, and model. In J. J. Martocchio (Ed.), Research in personnel and human resources management, vol. 23: 121-176. Oxford, UK: Elsevier, 2004.

PLOYHART, R. E.; Moliterno, T. P. Emergence of the human capital resource: A multilevel model. Academy of Management Review, 36: 127-150, 2011.

RABELO, N. S.; SILVA, C. E. Modelos de indicadores de Responsabilidade Socioambiental corporativa. Revista Brasileira de Administração Cientifica, Aquidabã, v.2, n.1, p. 5-30, 2011. Disponível em: <http://www.academia.edu/1818285/Modelos_de_indicadores_de_ responsabilidade_socioambiental_corporativa $>$. Acesso em: 8 de setembro de $\overline{2} 014$.

SANTOS, O.S. Líderes despreparados e a alta rotatividade nas empresas. Cultura \& Gestão Consultoria, 2013. Disponível em: $<$ http://culturaegestao.com.br/blog/lideres-despreparados-ea-alta-rotatividade-nas-empresas>. Acessoem: 30 de abril de 2015.

SAVITZ, A.W.; WEBER, K. The Triple Bottom Line: how today's best-run companies are achieving economic, social, and environmental success - and how you can too. San Francisco: JosseyBass, 2006.

SEN, S.; BHATTACHARYA, CB;KORSCHUN, D. The role of corporate social responsibility in strengthening multiple stakeholder relationships: A field experiment Journal of the Academy of Marketing Science 34 (2), 158-166, 2006.

SOMAYA, D.; WILLIAMSON, I. O.; LORINKOVA, N. Gone but not lost: The different performance impacts of employee mobility between cooperators versus competitors. Academy of Management Journal, 51: 936-953, 2008. 
SORRENTINO, M.; TRAJBER, R.; MENDONÇA, P. Educação ambiental como política pública. Educação e Pesquisa, São Paulo, v. 31, n. 2, p. 285-299, 2005.

STEEL, R. P.; LOUNSBURY, J. W. Turnover process models: Review and synthesis of a conceptual literature. Human Resource Management Review, 2014. Disponível em: <www.elsevier.com/ locate/humres>. Acesso em: 23 de abril de 2014.

TURBAN, D.; GREENING, G, D. Corporate social performance and organizational attractiveness to prospective employees. Academy of Management Journal, v. 40, n. 3, p. 658-672, 1997.

VIG, N. J.;KRAFT, M. E. (Eds.). Environmental policy: New directions for the twenty-first century. Washington, DC: CQ Press. 2010.

WAJNBERG, D.; LEMME, C.F. Exame da Divulgação do Relacionamento entre Iniciativas Socioambientais e Desempenho Financeiro Corporativo dos Bancos Brasileiros. Revista de Gestão Social e Ambiental. Jan. - Abr., v.3, nº.1, p.53-69, 2009.

WBCSD (WORLD BUSINESS COUNCIL FOR SUSTAINABLE DEVELOPMENT). Driving Success: Human Resources and Sustainable Development. University of Cambridge Programme for Industry. 2008.

WEYBRECHT, G. The Sustainable MBA: The manager's guide to green business. Chichester: Willey and Sons. 2010. 